\title{
SARS-CoV-2 Does Not Replicate in Aedes Mosquito Cells nor Present in Field-Caught Mosquitoes from Wuhan
}

\author{
Han Xia ${ }^{1,2} \cdot$ Evans Atoni ${ }^{1,2} \cdot$ Lu Zhao $^{1,2} \cdot$ Nanjie Ren ${ }^{1,2} \cdot$ Doudou Huang $^{1} \cdot$ Rongjuan Pei $^{1,2} \cdot$ Zhen Chen $^{1} \cdot$ \\ Jin Xiong ${ }^{1} \cdot$ Raphael Nyaruaba $^{1,2} \cdot$ Shuqi Xiao $^{1} \cdot$ Bo Zhang $^{1,2} \cdot$ Zhiming Yuan $^{1,2}$ (I)
}

Received: 10 May 2020 / Accepted: 8 June 2020 / Published online: 29 June 2020

(C) Wuhan Institute of Virology, CAS 2020

Dear Editor,

Severe acute respiratory syndrome coronavirus 2 (SARSCoV-2), the etiologic agent of COVID-19, is an enveloped, positive-sense single-stranded RNA virus that first discovered in December 2019 from a seafood market in Wuhan, China (Zhou et al. 2020). This novel coronavirus causes severe respiratory illness in humans, and a pandemic has been declared due to its worldwide spread.

Since early in the outbreak, several studies have been conducted with the aim of identifying all the possible ways through which the virus can be transmitted. Presently, respiratory droplets and human contact are considered the main transmission routes of SARS-CoV-2 (Jin et al. 2020). Moreover, several cases of person-to-person transmission of SARS-CoV-2 have been reported, especially among healthcare workers (Chan et al. 2020). At present, SARS$\mathrm{CoV}-2$ has been genetically linked closely to bats (BatCoV RaTG13) as its origin (Zhang et al. 2020; Zhou et al. 2020), and pangolins (Pangolin-CoV) as the intermediate host of the virus, may facilitate the virus transfer to human (Xiao et al. 2020). However, additional research studies should be conducted to fully identify all the possible routes of transmission of this virus.

Worldwide, mosquitoes are identified as highly effective vectors in transmitting various human and animal pathogens. Aedes albopictus $\mathrm{C} 6 / 36$ and Aedes aegypti Aag2 cells

Electronic supplementary material The online version of this article (https://doi.org/10.1007/s12250-020-00251-0) contains supplementary material, which is available to authorized users.

Zhiming Yuan

yzm@wh.iov.cn

1 Key Laboratory of Special Pathogens and Biosafety, Wuhan Institute of Virology, Center for Biosafety Mega-Science, Chinese Academy of Sciences, Wuhan 430071, China

2 University of Chinese Academy of Sciences, Beijing 100049, China are utilized primarily in virological studies due to their high degree of susceptibility. Indeed, Tettnang Virus-a coronavirus, has successfully been isolated from Aedes cantans mosquitoes in Czechoslovakia (Kozuch et al. 1979). Additionally, efficient replication of human enteric coronavirus (HEC) has been observed in the Aedes albopictus C6/36 cell line (Luby et al. 1999). Furthermore, among the common clinical features of SARS-CoV-2, some of the affected patients exhibited clinical gastrointestinal symptoms (Wang et al. 2020), thus implying that there might be similarity between this novel coronavirus and HEC viruses that affect the human intestinal tract. Presently, there are myths that mosquitoes might potentially carry or spread SARS-CoV-2, more so with the impending summer season approaching the mosquito breeding rate will be high. Hence, we aimed to investigate the infectivity range of SARS-CoV-2 in Aedes mosquito cell lines and the presence of the virus in the filed collected mosquitoes.

Four types of cell lines (Vero E6, C6/36, Aag2, and Sf9) were inoculated with a SARS-CoV-2 clinical isolate (nCoV-2019BetaCoV/Wuhan/WIV04/2019) at an MOI of $0.1,0.001$ or 0.00001 (3 replicates per group) alongside an uninfected negative control group. On the basis of previously conducted studies demonstrated that monkey kidney cell lines are particularly susceptible to SARS-CoV infection (Ksiazek et al. 2003; Zhou et al. 2020), we utilized Vero E6 cells as a positive control. Aliquots $(200 \mu \mathrm{L})$ from the supernatant were sampled at $0 \mathrm{~h}$ after inoculation and lysed in ACL buffer (Qiagen). Supernatants were collected every $24 \mathrm{~h}$ interval up to day 7 post inoculation (p.i.). Cells were viewed daily under a microscope, and the occurrence of cytopathic effect (CPE) was recorded.

SARS-CoV-2 replication in Vero E6 cells produced CPE starting from day 2 p.i., as all the different MOI cultures had attained the highest titer, $10^{9}$ copies $/ \mathrm{mL}$ (Fig. 1A). The CPE was focal, with cell rounding soon followed by cell detachment, and most of the cells died at 
A

SARS-CoV-2/Vero E6

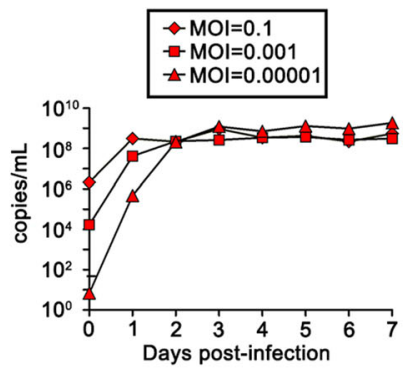

SARS-CoV-2/C6/36

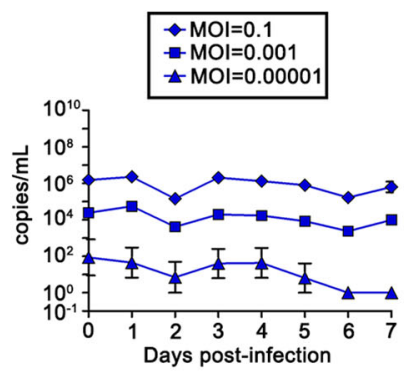

SARS-CoV-2/Aag2

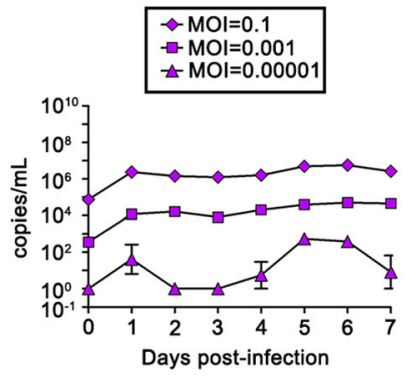

SARS-CoV-2/Sf9

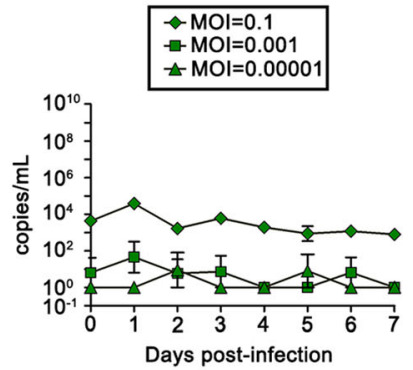

B
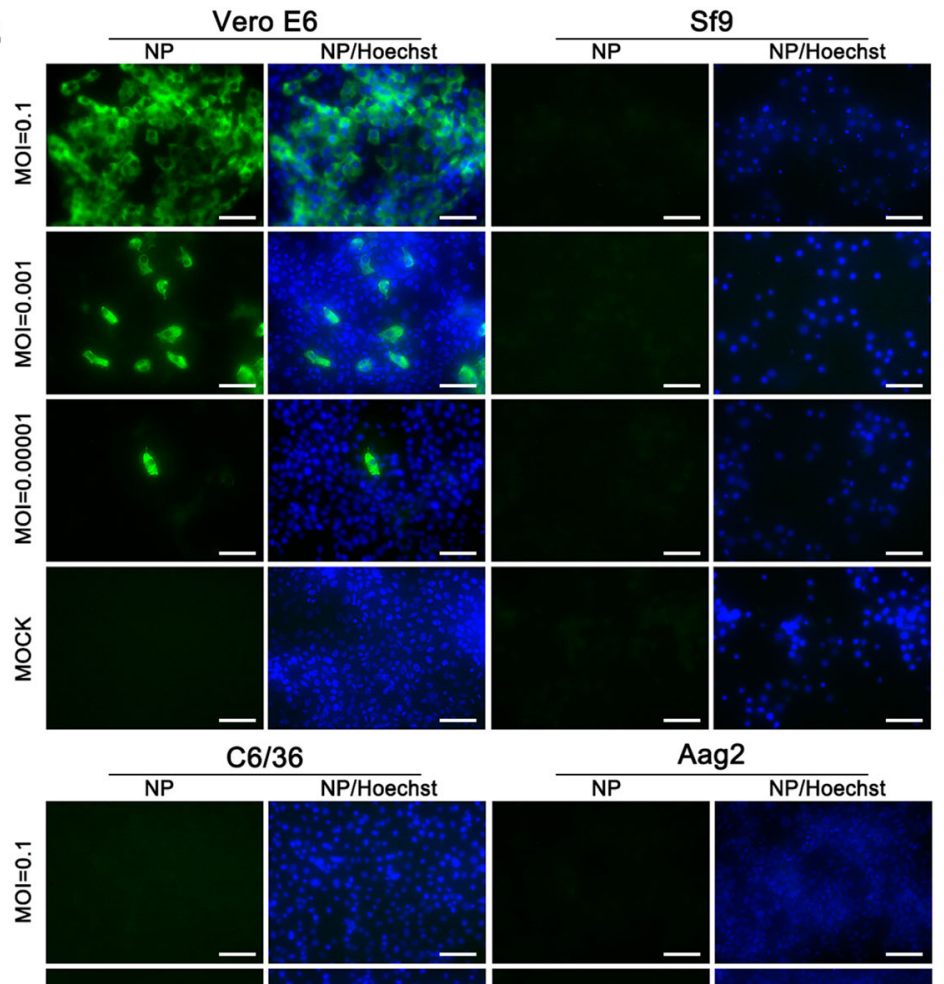

Aag2 NP/Hoechs

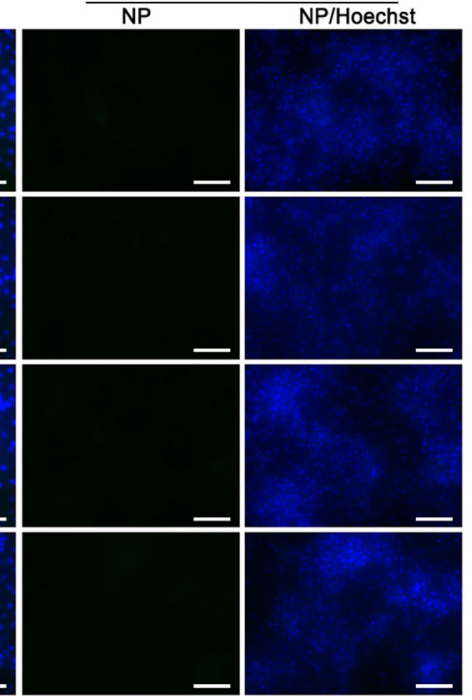

C

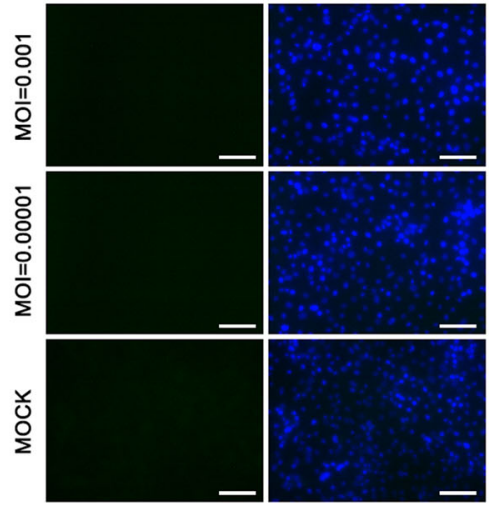

$114^{\circ} 0^{\prime} 0^{\prime \prime E}$

$114^{\circ} 30^{\prime} 0^{\prime \prime} E$

$115^{\circ} 0^{\prime} 0^{\prime \prime E}$

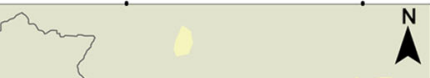

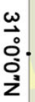

$\omega$
$\overrightarrow{0}$
0
$z$
$z$

Residential area close to
Huanán seafood market

Dongxihu.

Huangpi

o. Pig Farm at Caizha

- Xinzhour

Jiangan

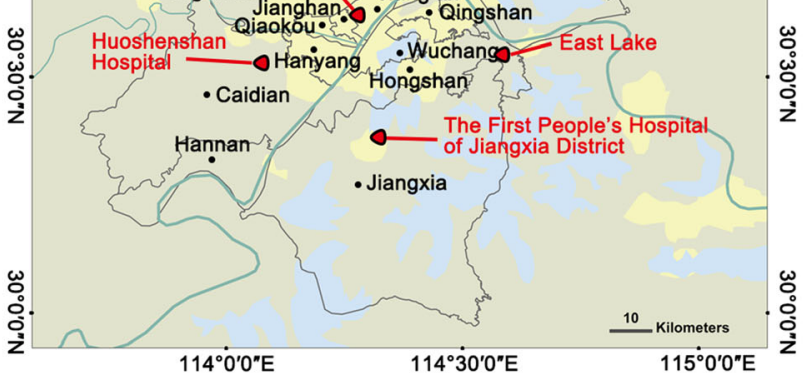


4 Fig. 1 Replication of SARS-CoV-2 in different cell lines and field mosquitoes collected. A SARS-CoV-2 RNA copies detected in Vero E6 cells, C6/36 cells, Aag2 cells, and Sf9 cells evaluated using qRTPCR at different time points after innoculation. Each cell line was repeated three times. B Indirect immunofluorescence assay (IFA) to detect the NP protein of SARS-CoV-2 in the four tested cell lines at $36 \mathrm{~h}$ post-inoculation. Bars, $100 \mu \mathrm{m}$. C Location of mosquito trap sites in the region of Wuhan City, China. Black dots stand for the 13 administrative districts of Wuhan, and Red triangles are the mosquito collection sites.

day 7 p.i.. In contrast, C6/36, Aag2 and Sf9 cells did not produce a SARS-CoV-2-specific CPE up to day 7 p.i. (Supplementary Figure S1). Quantitative RT-PCR analysis established that there was no viral replication in these three insect cell lines $(P>0.05)$ per the titer load (Fig. 1A). This result was also confirmed through an indirect immunofluorescence assay (see supplementary methods for details about the assay), which established active viral NP protein expression in the Vero E6 cell lines, whereas there was no expression in mosquito C6/36, Aag2 and Sf9 cells (Fig. 1B). In addition, no CPE was observed when the supernatant harvested at day 7 p.i. from C6/36, Aag2, and Sf9 cells was reinoculated back into Vero E6 cells.

To detect whether field mosquitoes contain SARS-CoV-2, a total of 1165 Culex and Anopheles mosquitoes were collected from various sites with different habitat containing urban residential, hospital and scenic area, and farm in rural region of Wuhan during April and May in 2020 (119 mosquitoes from a residential area close to Huanan seafood market, 73 from East Lake region, 104 from First People's Hospital of Jiangxia District, and 235 from Huoshenshan Hospital region, 634 from pig farm in Huangpi District) (Fig. 1C and Supplementary Table S1). The mosquitoes were taxonomically classified and thereafter divided into 58 pools, including 884 Culex and 281 Anopheles mosquitoes (Supplementary Table S1). The SARS-CoV-2 specific qRT-PCR detection assay determined that all the tested mosquito pools were negative for the virus (see supplementary methods for details about the assay).

Mosquito-borne viruses infect both susceptible vertebrate hosts and mosquitoes. For a mosquito to be considered a competent vector of a virus, the virus should be able to infect and pass through the midgut barrier and be disseminated to the salivary glands (Franz et al. 2015; Huang et al. 2019). Moreover, a virus need appropriate receptors in the respective cells to establish successful infection. Several studies have demonstrated that SARS-CoV-2 uses angiotensin-converting enzyme 2 (ACE2) as its receptor to enter cells (Zhou et al. 2020). In some susceptible vertebrate hosts, ACE2 is expressed mainly on the outer surface of cells in the lungs, arteries, heart, kidneys, and intestines (Donoghue et al. 2000; Hamming et al. 2004). In mammals, ACE has a key role in regulating the levels of several circulating peptides. ACE has been described in insects such as Drosophila melanogaster and Anopheles stephensi, but its actual function in these insects is still unclear (Isaac et al. 1998; Ekbote et al. 1999). Therefore, it is crucial that the actual role of ACE in insects needs to be investigated further. Herein, we did not conduct an in vivo mosquito vector competence study on SARS-CoV-2, which we consider as one caveat of this study.

In this study, we conclude that SARS-CoV-2 does not replicate in Aedes cells C6/36 and Aag2 in vitro nor present in the field collected Culex and Anopheles mosquitoes, thus supporting that mosquitoes cannot spread SARS-CoV-2. Therefore, mosquitoes do not pose a threat regarding the transmission of SARS-CoV-2.

Acknowledgements The project is completed by National Biosafety Laboratory, Wuhan, Chinese Academy of Sciences. We are particularly grateful to the running team of the laboratory for their work. We sincerely thank Prof. Zhengli Shi of Wuhan Institute of virology, Chinese Academy of Sciences, for providing us a clinical isolate of SARS-CoV-2 and antibody for this study. This work was supported by the Ministry of Science and Technology of the People's Republic of China (2020YFC08845600); the National Health Commission of the People's Republic of China (2018ZX10711001-006).

\section{Compliance with Ethical Standards}

Conflict of interest The authors declare that they have no conflict of interests.

Animal and Human Rights Statement This article does not contain any studies with human or animal subjects performed by any of the authors.

\section{References}

Chan JF-W, Yuan S, Kok K-H, To KK-W, Chu H, Yang J, Xing F, Liu J, Yip CC-Y, Poon RW-S, Tsoi H-W, Lo SK-F, Chan K-H, Poon VK-M, Chan W-M, Ip JD, Cai J-P, Cheng VC-C, Chen H, Hui CK-M, Yuen K-Y (2020) A familial cluster of pneumonia associated with the 2019 novel coronavirus indicating person-toperson transmission: a study of a family cluster. The Lancet 395:514-523

Donoghue M, Hsieh F, Baronas E, Godbout K, Gosselin M, Stagliano N, Donovan M, Woolf B, Robison K, Jeyaseelan R, Breitbart $\mathrm{RE}$, Acton S (2000) A novel angiotensin-converting enzymerelated carboxypeptidase (ACE2) converts angiotensin I to angiotensin 1-9. Circ Res 87:E1-E9

Ekbote U, Coates D, Isaac RE (1999) A mosquito (Anopheles stephensi) angiotensin I-converting enzyme (ACE) is induced by a blood meal and accumulates in the developing ovary. FEBS Lett 455:219-222

Franz AW, Kantor AM, Passarelli AL, Clem RJ (2015) Tissue barriers to arbovirus infection in mosquitoes. Viruses 7:3741-3767

Hamming I, Timens W, Bulthuis ML, Lely AT, Navis G, van Goor H (2004) Tissue distribution of ACE2 protein, the functional 
receptor for SARS coronavirus. A first step in understanding SARS pathogenesis. J Pathol 203:631-637

Huang YS, Higgs S, Vanlandingham DL (2019) Arbovirus-mosquito vector-host interactions and the impact on transmission and disease pathogenesis of arboviruses. Front Microbiol 10:22

Isaac RE, Schoofs L, Williams TA, Corvol P, Veelaert D, Sajid M, Coates D (1998) Toward a role for angiotensin-converting enzyme in insects. Ann N Y Acad Sci 839:288-292

Jin YH, Cai L, Cheng ZS, Cheng H, Deng T, Fan YP, Fang C, Huang D, Huang LQ, Huang Q, Han Y, Hu B, Hu F, Li BH, Li YR, Liang K, Lin LK, Luo LS, Ma J, Ma LL, Peng ZY, Pan YB, Pan ZY, Ren XQ, Sun HM, Wang Y, Wang YY, Weng H, Wei CJ, Wu DF, Xia J, Xiong Y, Xu HB, Yao XM, Yuan YF, Ye TS, Zhang XC, Zhang YW, Zhang YG, Zhang HM, Zhao Y, Zhao MJ, Zi H, Zeng XT, Wang YY, Wang XH, For the Zhongnan Hospital of Wuhan University Novel Coronavirus Management and Research Team, Evidence-Based Medicine Chapter of China International Exchange and Promotive Association for Medical and Health Care (CPAM) (2020) A rapid advice guideline for the diagnosis and treatment of 2019 novel coronavirus (2019-nCoV) infected pneumonia (standard version). Mil Med Res 7:4

Kozuch O, Nosek J, Gresikova M, Labuda M, Sekeyova M, Chmela J (1979) Isolation of Tettnang virus from ticks, mosquitoes and small rodents. Acta Virol 23:86-88

Ksiazek TG, Erdman D, Goldsmith CS, Zaki SR, Peret T, Emery S, Tong S, Urbani C, Comer JA, Lim W, Rollin PE, Dowell SF,
Ling AE, Humphrey CD, Shieh WJ, Guarner J, Paddock CD, Rota P, Fields B, DeRisi J, Yang JY, Cox N, Hughes JM, LeDuc JW, Bellini WJ, Anderson LJ, SARS Working Group (2003) A novel coronavirus associated with severe acute respiratory syndrome. N Engl J Med 348:1953-1966

Luby JP, Clinton R, Kurtz S (1999) Adaptation of human enteric coronavirus to growth in cell lines. J Clin Virol 12:43-51

Wang J, Wang D, Chen GC, Tao XW, Zeng LK (2020) SARS-CoV-2 infection with gastrointestinal symptoms as the first manifestation in a neonate. Chin J Contemp Pediatr 22:211-214 (in Chinese)

Xiao K, Zhai J, Feng Y, Zhou N, Zhang X, Zou JJ, Li N, Guo Y, Li X, Shen X, Zhang Z, Shu F, Huang W, Li Y, Zhang Z, Chen RA, Wu YJ, Peng SM, Huang M, Xie WJ, Cai QH, Hou FH, Chen W, Xiao L, Shen Y (2020) Isolation of SARS-CoV-2-related coronavirus from Malayan pangolins. Nature. https://doi.org/ 10.1038/s41586-020-2313-x

Zhang T, Wu Q, Zhang Z (2020) Probable pangolin origin of SARSCoV-2 associated with the COVID-19 outbreak. Curr Biol 30(1346-1351):e1342

Zhou P, Yang XL, Wang XG, Hu B, Zhang L, Zhang W, Si HR, Zhu Y, Li B, Huang CL, Chen HD, Chen J, Luo Y, Guo H, Jiang RD, Liu MQ, Chen Y, Shen XR, Wang X, Zheng XS, Zhao K, Chen QJ, Deng F, Liu LL, Yan B, Zhan FX, Wang YY, Xiao GF, Shi ZL (2020) A pneumonia outbreak associated with a new coronavirus of probable bat origin. Nature 579:270-273 